PAPER

\title{
Medical humanities and medical alterity in fiction and in life
}

\author{
Brian Hurwitz
}

\section{Correspondence to}

Dr Brian Hurwitz, Centre for the Humanities and Health, King's College London, Virginia Woolf Building, 22 Kingsway, London WC2B 6NR, UK ; brian.hurwitz@kcl.ac.uk

The argument in this paper is based on research set out in Hurwitz B, Healthcare serial killings: was the case of Dr Harold Shipman unthinkable? ${ }^{10}$ and is a development and adaptation of 'Dark Doctoring Types in Fiction and in Life', published in StatusQuaestionis 2014 6: http://statusquaestionis. uniroma1.it/index.php/ statusquaestionis/issue/view/ 1012/showToc

Received 24 September 2014 Accepted 2 October 2014

\section{CrossMark}

To cite: Hurwitz B. J Med Ethics 2015:41:64-67.

\section{ABSTRACT}

A widely accepted component of any answer to the question 'What is it to do good medical ethics?' is the commitment to benefit people's health, in principlist terminology, 'beneficence'. This paper addresses deliberate maleficence and the cultural otherness with which it is associated, focusing on the activities of the serial killer Dr Harold Shipman. It finds an uncanny 'fit' between the normal operation of healthcare services and this sort of alterity which has attracted little attention from bioethicists but has been addressed by novelists. To the extent that the medical humanities offers useful insights into hard moral problems, its capacities rest on taking account of both the fictional and the real.

Imagine a world in which healthcare staff no longer subscribe to the principle of beneficence, or do so erratically and unpredictably. Beneficence is so often watered down by respect for autonomythat 'first among equals' of moral principles running counter to it ${ }^{1}$-that one wonders how determinative it may be of good healthcare. ${ }^{2}$ Imagine now that doctors no longer manifest the character traits and dispositions to act for the good of others or that they oscillate in doing so. What then? What would healthcare look like if its principal actors relied on quite different moral virtues, dispositions and motivational drives from those we associate with doctoring, if they were intermittently to crave patient harm? Variability of healthcare outcomes might make the consequences of such traits difficult to see. ${ }^{3-5}$

Imagine now a darker possibility, one in which such contrarian practitioner traits are systematically directed against the medical and healthcare interests of patients. Not long ago, a situation like this arose within the UK National Health Service (NHS). For a long time, hardly anyone noticed, or noticed in a way that led to his apprehension. ${ }^{6}$ It concerned a general practitioner (GP), Harold Shipman, who killed his patients in a way that was mistaken for benevolence:

I genuinely thought he was a great doctor, very intelligent. I went to see him with different things, and he always had time to talk. You would expect to be kept waiting but you accepted it because you knew he would spend time with you. There was a year-long wait to get onto his list: he was the most popular doctor in Hyde.?

I remember the time [he] gave to my Dad. He would come around at the drop of a hat. He was a marvellous GP apart from the fact that he killed my father. ${ }^{8}$
Aspects of Shipman's medical practice later came to light which revealed that he was not straightforwardly a good doctor: he had lost a civil action for medical negligence, had faced health service complaints that were upheld, was shown to be a poor (and deliberately inaccurate) record keeper and to have assumed that no effort should be made to resuscitate people he said had become acutely ill at home. ${ }^{9}$ For nearly three decades, Shipman continued to practise - and to kill-in apparent coexistence with the beneficence-oriented NHS. ${ }^{10}{ }^{11}$ The fit between such medical alterity and the apparently normal operation of the health service has hardly attracted notice from bioethicists ${ }^{9}{ }^{12}$ though it has long been a focus for novelists.

In 1905, the Swedish writer, Hjamar Söderberg, published Doctor Glas, a novel unfolding as the private diary of a GP setting out his decision to murder a patient, the clergyman, Gregorius. Dr Glas is attracted to the parson's wife, Helga (also his patient) and gives Gregorius a pill telling him it is for his heart. Within minutes Gregorius drops dead (from cyanide poisoning). 'I heard the clergyman's tumbler fall over on the tray. I did not want to look, yet I saw his arm fall limply down and his head nod on his breast ...I myself wrote out the death certificate. ${ }^{13}$

Paperwork is often the last act of a medical murderer, in fiction and in fact. ${ }^{14}$ By activating the civil mechanisms authorising disposal of dead bodies, it helps ensure foul play masquerades as natural death. As the forensic pathologist Keith Simpson has indicated, such a possibility has long been appreciated but perhaps not always guarded against:

\footnotetext{
Doctors are in a particularly good position to commit murder and escape detection. 'Dangerous drugs' and powerful poisons lie in their professional bags or in the surgery. No one is watching or questioning them, and a change in symptoms, a sudden 'grave turn for the worse' or even death is for them alone to interpret. They can authorize the disposal of a dead body by passing the death certificate to the Registrar of Deaths... Are there many doctor murderers? Or are doctors above suspicion? ${ }^{15}$
}

Simpson hints at how difficult it can be to confront ingrained cultural assumptions and stereotypes about doctoring. When Doctor Glas first appeared in Scandinavia it was felt to be a deeply unsettling work because it exposed the callous mentality of a doctor debating with himself the propriety of murderous malevolence. Similar thoughts play out in Francis Iles's 1931 novel, Malice Aforethought, whose opening lines set the tone: 
It was not until several weeks after he had decided to murder his wife that Dr Bickleigh took any active steps in the matter. Murder is a serious business. The slightest slip may be disastrous. Dr Bickleigh had no intention of risking disaster. ${ }^{16}$

The work is an expose of the unbridled power a country GP enjoyed in the interwar years, its plot turning on how he plans to kill his wife, Julia:

Dr Bickleigh did not think of what he proposed as 'murder' at all. Not that he consciously avoided the word. ... Other people 'murdered' their wives, but other people's cases were different. ... In his duties he had put away plenty of pet animals who had passed their usefulness. Now the time had come to put Julia away. ${ }^{16}$

He laces her food with a chemical that causes excruciating head pains from which Julia gains relief only by taking opiates which she learns to administer herself by injection. When Bickleigh administers a fatal overdose he passes it off as suicide. In preparation for the act, he mentally divests Julia of her individuality, a process shared by other perpetrators who dehumanise victims 'to render them as animal like, or as nothing., ${ }^{, 17}$

The novelist P D James notes that medical killings demand of perpetrators an unusual degree of imperturbability, a sangfroid that enables them to return to clinical practice as if nothing unusual has happened. When superintendent Dalgliesh in A Mind to Murder (1963) is called to investigate the death of Miss Bolam, an administrative officer of a west London psychiatric clinic, he finds below the calm exterior of its Georgian façade a set of seething relationships. The culprit, he concludes, must be among them: 'Miss Bolam, dull, ordinary unremarkable Enid Bolam who had inspired so much hate in someone... As private as that unknown member of staff who would be at the clinic on Monday morning, dressed as usual, looking the same as usual, speaking and smiling as usual and who was the murderer. ${ }^{18}$

Literary exploration of grotesque medical inversion plays on our fears of a loss of orderliness in healthcare, on its arrangements becoming contingent on goals and purposes disconnected from ethical principles such as beneficence. Large-scale institutions are seen to be manipulable, subject to gaming by agents not signed up to the core values of healthcare. John Collee's A Paper Mask (1987) reveals how easily medical power can be assumed without any training or authority. The novel concerns Mathew Harris, a hospital porter, who steals a doctor's medical certificates after he's been killed in a road traffic accident and assumes his identity. Harris starts with the advantage of an insider's understanding of the organisational culture and workings of a hospital. Beginning work in casualty with training provided only by reading a few hastily gathered textbooks, he causes harm to those he attends to and is able to maintain the role through the support of a gullible yet highly competent nurse, who mistakes his complete ignorance for inexperience and the consequences of a poor medical education. ${ }^{19}$

Ease of gaining access to the inner workings of a hospital for purposes quite contrary to its purposes is at the centre of Robin Cook's thriller Coma (1977), in which a medical student finds a hospital's oxygen supply has been tampered withre-engineered-to deliver intermittent shots of carbon monoxide to people undergoing elective surgery. ${ }^{20}$ Patients emerge from routine operations brain dead and are transferred to the Jefferson Institute, a medical facility that elaborately preserves and warehouses heart-beating cadavers for their stem cells and organs.
Plots such as these go beyond anxiety about detecting regulatory misconduct, 'bad apples' in an otherwise untainted medical orchard. Catherine Belling, a medical humanities scholar, believes that fiction in relation to the clinic needs to be understood not as fantasy or 'fanciful escape' but as works of the imagination that 'apprehend (often anxiously) the realities we cannot grasp in other ways. ${ }^{, 21}$ Fiction conjures with functioning healthcare systems of an antisense type, staffed by denizens of different moral outlook from those entrusted with medical care in real life. While fictional work can supply 'additional role models... [and] the complexity of the moral dimension of medicine' which some ethicists have turned to in teaching bioethics, ${ }^{22}$ the texts discussed here pose novelistic hypotheses and healthcare scenarios which confront readers with non-beneficient care grounded not merely on lapses of procedure or standards, but on moral otherness embedded in the healthcare system.

Although healthcare is not a novel, fictional world-making continues to throw up dark counterparts to the staff of today's welfare state. $^{23-25}$ Can such works contribute to making sense of the life and work of a medical murderer such as Harold Shipman? From the very outset of his career in 1970, Shipman killed people who were neither terminally ill nor in intractable pain. Women aged 75 years or above were the largest group, although men made up nearly a quarter of his victims, as well as people under 65 years of age. ${ }^{6}$ Dame Janet Smith chaired the public inquiry into his activities, which delivered 180 verdicts of 'unlawful killing' and found 'cause for suspicion of unlawful killing' in a further 45 , by which it meant 'Shipman probably killed the patient,' a verdict settled on 'where the evidence was clearly weighed on the side of guilt." ${ }^{6}$ Add to this tally the 15 murders Shipman was convicted of in court and the toll reaches 240 killings.

Even after chairing the inquiry, Dame Janet Smith was unable to grasp the full enormity of Shipman's significance:

I still do feel it was unspeakably dreadful, just unspeakable and unthinkable and unimaginable that he should be going about day after day pretending to be this wonderfully caring doctor and having with him in his bag his lethal weapon ... which he would just take out in the most matter of fact way. ${ }^{26}$

In Shipman she found something unassimilable. The weapon that so chilled her was a syringe loaded with diamorphine. Typically, Shipman would call round in the afternoon when elderly patient-victims were alone at home (who else but a GP is culturally sanctioned to access hundreds of homes and invite himself round for a friendly chat and a lethal injection?). $\mathrm{He}$ would report the death as having occurred in his presence, from a heart attack or stroke, or leave the body to be found later in the day by a relative or friend. Shipman would complete the death certificate giving a plausible but false story of pre-existing disease and press the relatives to cremate the body, so destroying toxicological evidence.

The barrister and psychiatrist, Dr B Mahendra, argues that the medical profession was complacent to see Shipman simply as 'a purveyor of evil ... a perverted 'one-off', ${ }^{27}$ because it distracted attention from how such killings could become a routine aspect of the NHS. As Richard Baker and I have argued, killing can only ever be routine-as in the novel Coma-where obstacles to its accomplishment have been fully annulled, 'where all, or almost all, health service and civil systems for monitoring... around the time of a patient's death, are so inadequate as to allow murder in the same way, by the same means, by the same man, to become repeated and established over decades. ${ }^{28}$ But equation of Shipman with evil stemmed also from failure of 
biographical and psychological studies to account for his actions. He never admitted wrongdoing, showed no remorse, and refused to speak to psychiatrists. His family has never shed light on his personal world (Shipman committed suicide in Wakefield Prison in January 2004). No credible link can be established between Shipman's clinicidal programme and psychological state, drive, sense of purpose or motive. It is therefore not possible to bring his actions into relationship with anything verifiable about his psychological make-up. ${ }^{29}$ This makes his actions strictly incomprehensible, akin to the unintegratable 'other' Levinas identified with 'radical evil'. ${ }^{30}$

How does it help to see Shipman's alterity through a fictional lens? Bernard Williams held that the way to 'understand people's behaviour in terms of virtues and vices is in terms of stereotypes or standard images... rang[ing] from crude 'characters' and more individuated outlines constructed with the help of type drawn, often, from fiction. ${ }^{31}$ This is not to endow fiction with the same sort of wordly referentiality as a witness statement or a history, but to appreciate it for its capacity to take on board moral possibilities beyond (though not excluding) the familiar and the real. Behind the idealised and comforting figures of trustworthy and caring doctors, fiction performs in terrible detail what Keith Simpson in the extract of his Forty Years of Murder $^{15}$ quoted above only felt able to intimate.

Fiction cannot stand-in for the missing inner life, thoughts or motives of a particular criminal, but by absorbing cultural ambivalences about doctoring and instabilities of medical stereotypes, symbolic exchange between virtues and vices become apparent. Shipman incarnated such instabilities in a highly intensified form. Emerging from a UK medical school to become a respected figure within the NHS in his locality, he displayed qualities sought after by locals. Even after his convictions, people remained strikingly complimentary about him, suggesting a classificatory confusion and in-between status in which good and bad qualities can comingle. Such a formulation suggests a type-antitype analysis that positions Shipman as an antitype, something 'shadowed forth' in the guise of a type. The term comes from the Latin antitypus, meaning 'responding as an impression to the die', 32 formed by the same structures, processes and forces that shape the type. Compared with the type, antitypes display contrastive features 'more intense and more significant than their types'. ${ }^{33}$ Shipman's willingness to visit at home without even being requested to was just such a distinctive and unstable benevolent/malevolent feature.

Data on home-visiting rates are not routinely collected in the UK, but Shipman's reputed position way above the curve of declining visiting rates might have been a clue to his character and activities. ${ }^{34}$ Patients clearly valued this malevolent propensity which was uncannily imprinted on his mortality profile. ${ }^{10}$ Shipman's deaths peaked on weekdays between $1 \mathrm{pm}$ and $6 \mathrm{pm}$, the time when he undertook home visits, $12 \%$ occurring then compared with $2 \%$ in comparator practices, and his deaths were lower than average on Sundays when he was generally not at work. A review of his clinical notes found he had been at the bedside in 19\% of deaths compared with a GP presence in comparator practices of only $1 \%$, and relatives and carers were $50 \%$ less likely to have been present than at deaths in comparator practices. ${ }^{10}$

In the 12 months before his arrest in 1998, Shipman was killing someone, on average, every 10 days. Shipman's complete embeddedness in the NHS is foreshadowed by the novel Coma, but so well did his operation fit within the NHS that little in the way of 'redesign' was required to accommodate his purposes. The major change he effected enabled him to obtain large supplies of the controlled drug, diamorphine, which he achieved through overprescribing to patients with terminal illnesses and collecting the unused amounts after (natural) death.

To fictional depictions of malevolent doctors, Shipman has added the habits and propensities of a real medical murderer trading on the special position of UK GPs trusted and welcomed into people's homes. When Shipman asked his patients to roll-up their sleeves in expectation of a beneficent injection he would have seen the unquestioning looks on their faces as he felt their pulses and watched their breathing, as both drained painlessly away.

Injection is the method of choice of healthcare serial killers 'followed by suffocation, poisoning, and tampering with equipment', ${ }^{35}$ the US killer, Swango, adopting the variant of administering massive overdoses of patients' usual medication. ${ }^{10}$ Between 1990 and 2006, 90 health professionals worldwide faced prosecution for serial killing of whom half had been convicted by the time of the publication of a systematic review. Nurses comprised $86 \%$ of prosecutions, doctors $12 \%$ and allied health professionals $2 \%$. The number of legally proven murders came to 317 , and of suspicious patient deaths, $2113 .^{35}$

These figures challenge the view that Shipman was a 'one-off'. Judged by modifications made to UK death certification and cremation procedures he has not been treated as such. Neither the fictional nor the real tells us when, where, or how transgression on this scale may reappear in health care services, but further research into how stereotypes of beneficence and maleficence are culturally created and symbolically constituted promises greater insights into how they influence patient preferences in choosing a good doctor.

\section{Competing interests None.}

Provenance and peer review Commissioned; internally peer reviewed.

\section{REFERENCES}

1 Gillon R. Ethics needs principles - four can encompass the rest-and respect for autonomy should be "first among equals". J Med Ethics 2003:29;307-12.

2 Downie R, Macnaughton J. Bioethics and the humanities: attitudes and perceptions. Abingdon: Routledge-Cavendish 2007;36-41.

3 Mohammed $M$, Cheng $M$, Rouse $A$, et al. Bristol, Shipman and clinical governance: Shewhart's forgotten lessons. Lancet 2001:357;463-67.

4 Spiegelhalter D, Best N. Shipman's statistical legacy. Significance 2004:1:10-12. doi:10.1111/j.1740-9713.2004.00002.x.

5 Aylin $P$, Best $P$, Bottle $A$, et al. Following Shipman: a pilot system for monitoring mortality rates in primary care. Lancet 2003:362;485-91.

6 Smith J. The Shipman Inquiry. For Reports 1-6 see The Shipman Inquiry, Manchester 2003-2005: http://webarchive.nationalarchives.gov.uk/20090808154 959/http:/www.the-shipman-inquiry.org.uk/reports.asp (accessed 12 Sep 2014).

7 Whittle B, Ritchie J. Prescription for murder. London: Warner Books, 2001.

8 Rudol C, Barkham, P. The Shipman report. The Times, 20 Jul 2002.

9 Davies M. Harold Shipman. In: Davies M, eds. Medical self-regulation: crisis and change. Aldershot: Ashgate, 2007;221-42.

10 Baker R. Harold Shipman's Clinical Practice 1974-1998. London: Department of Health, 2001.

11 Hurwitz B. Healthcare serial killings: was the case of Dr Harold Shipman unthinkable? In: Griffiths D, Sanders A, eds. Bioethics, medicine and the criminal law, Volume 2: medicine, crime and society. Cambridge: Cambridge University Press, 2001:13-42.

12 Cooper RJ. Solo doctors and ethical isolation. J Med Ethics 2002:35:692-5.

13 Söderberg H. Doctor Glas. Translated from the Swedish by P.B. Austin. London: Harvill Press, 2002:115.

14 Havard J. The detection of secret homicide. London: Macmillan and Co Ltd. 1960:103,112.

15 Simpson K. Forty years of murder. London: Harrap 1978:253.

16 Iles F. Malice aforethought. London: Gollancz 1931. http://www.orionbooks.co.uk/ books/malice-aforethought-paperback, London: Orion. 7, 130.

17 Zimbardo P. The Lucipher effect. How good people turn evil. London: Rider division of Random House, 2007:291.

18 James PD. A mind to murder. London: Faber and Faber, 2010:148.

19 Collee J. A paper mask. London: Viking, 1987.

20 Cook R. Coma. Boston Little Brown \& Co, Boston, 1977.

21 Belling C. Depth perception. Genre 2013:44;3, at 260, 239-61. 
22 Coluehan J. Written role models in professionalism education. Med Humanit 2007:33:106-9.

23 Macdonald M. The language of fiction. Proceedings of the Aristotelian Society Supplementary Volumes, Vol. 28;1955:165-96.

24 Cebik B. The world is not a novel. Philos Lit 1992:16(1):68-87.

25 John E. Reading fiction and conceptual knowledge: philosophical thought in literary context. J Aesthetics Art Criticism 2013;56;(4):331-48.

26 Smith J. John Hunt Lecture given by Dame Janet Smith as mentioned on the RCGP webpage: http://www.i-newswire.com/dame-janet-smith-defends-recommendations/ a34462

27 Mahendra B. Killer facts, could there be another Shipman? New Law J 2002;152:1189.

28 Baker $R$, Hurwitz $B$. Intentionally harmful violations and patient safety: the example of Harold Shipman. In: Hurwitz B, Sheikh A, eds. Health care errors and patient safety. BMJ Books Wiley Blackwell, 2009;33-55.
29 Gunn J. Dr Harold Frederick Shipman: an enigma. Crim Behav Ment Health 2010:20:190-8

30 Bernstein R. Radical evil, a philosophical interrogation. Cambridge: Polity Press, 2002;11.

31 Williams B. Ethics. In: Grayling AC, ed. Philosophy: a guide through the subject. Oxford, OUP, 1995:546-82 at 574

32 Oxford English Dictionary Online. Oxford: Oxford University Press, 2011. http:// www.oed.com/view/Entry/8913? redirectedFrom=antitype\#eid.

33 Berkeley B. Some misapprehensions of Christian typology in recent literary scholarship. Studies in English Literature 1500-1900 1978,3-12.

34 Aylin P, Majeed A, Cook D. Home visiting by general practitioners in England and Wales. BMJ 1996:313:207.

35 Yorker B, Lampe $P$, Forrest $A$, et al. Serial murder by healthcare professionals. J Forensic Sci 2006;51:1363-71. 